\title{
Remaking "Nature": The Ecological Turn in Dutch Water Management
}

\author{
Cornelis Disco \\ University of Twente
}

\begin{abstract}
The ecological turn in water management has usually been interpreted as a political and cultural rather than technical and professional accomplishment. The dynamics of the uptake of ecological expertise into hydraulic engineering bureaucracies have not been well described. Focusing on the controversy around the damming of the Oosterschelde estuary in the Netherlands in the 1970s, this article shows how public environmental politics transformed the politics of interprofessional competition. Andrew Abbott's concept of "jurisdictional vacancies" is mobilized to illuminate how ecologists took advantage of the political bankruptcy of the Dutch coastal engineering agency to extend their professional jurisdiction. The subsequent "ecologization" of Dutch coastal engineering was successful, however, only because the ecologists were able and willing to adapt their practices to the professional culture of the hegemonic civil engineers.
\end{abstract}

\section{Technology, Ecology, and Professions}

It is now widely appreciated that what used to be called "progress" or even "the march of civilization" has exacted a significant ecological price (Beck 1992; Carson 1964; Hajer 1995). The expansion of human settlement has destroyed the natural habitats of other species, and industrialization has altered subtle chemical and physical balances in the biosphere in ways that are poorly understood, likely to our peril. However, this knowledge has also spurred counterefforts. Projects to clean up polluted land and water and reduce ongoing levels of pollution vie with efforts to restore original prehuman habitats and ecotopes. While such projects may be marginal in the face of what has been done and is still being done to "nature," they do betray a

\footnotetext{
AUTHOR'S NOTE: Thanks to Arie Rip and Ibo van de Poel for constructive comments on earlier versions of this article. Members of the Department of Science and Technology Studies at the University of Twente and anonymous referees of this journal also leveled helpful criticisms. Some of the research for this article was carried out in the context of the Technology in the Netherlands in the Twentieth Century (TIN-20) program, funded in part by the Netherlands Organization for Scientific Research (NWO).
}

Science, Technology, \& Human Values, Vol. 27 No. 2, Spring 2002 206-235

(C) 2002 Sage Publications 
new attitude or perhaps even a new "ecological compact" with significant economic and political impacts.

In general, the assault on nature has been an unintended by-product of other human activities, for example: agriculture, war, and industrial production. In most cases, therefore, the present reorientation involves developing consciousness about damage that has been done, is being done, or could potentially be done. On the basis of these insights, practices can be modified so as to eliminate or mitigate the unintended effects. An entirely new vocabulary of risk, especially ecological risk, has emerged to articulate the consequences of the fact that ordinary practices increasingly produce unintended consequences for the natural environment (Beck 1992; Lash, Szerszinski, and Wynne 1996). In this article, I address another type of situation, in which the assault on nature is deliberate and purposive. In these settings, the explicit aim is to destroy unruly, "primal" nature and replace it with a new and purportedly more benign "humanized" nature. Here, ecological consciousness about damage being done to nature must confront the perceived benefits to be had from precisely such "damage." Large-scale hydraulic engineering projects are very clear examples of such interventions (e.g., flood control schemes and large irrigation or hydroelectric power dams). To investigate the technopolitical dynamics that are unleashed by the new ecological consciousness in such ambiguous situations, I describe and analyze the final phases of a large flood control project in the Netherlands: the so-called Delta Works. This project was launched to general acclaim in 1953 in the wake of a massive and very destructive flood. By the early 1970s, however, it was foundering under a barrage of ecological critiques so intense that for the final stages, an entirely new solution had to be engineered. This was not simply a question of new criteria and designs; it required a thoroughgoing transformation of technological traditions and mentalities rooted in the intimate dialectic between Dutch civilization and water.

Much of the territory of the present-day Netherlands is routinely habitable only thanks to the incessant renewal and maintenance of a complex system of waterworks that keep the sea and rivers at bay (van Veen 1962; van der Ven 1993). This system has been in the making for over a thousand years. During this time, the Dutch have struggled with varying degrees of success to maintain a precarious hold on their low-lying delta by digging elaborate networks of drainage ditches and canals, building dikes along rivers and vulnerable stretches of seacoast, damming tidal rivers and bays, and claiming (and reclaiming) land by means of the management of natural accretion or different systems of mechanical pumping. This venerable hydraulic tradition respected but did not esteem nature. It conceived nature, especially water, as an antagonist (the "hereditary enemy") that took lives and property whenever 
and wherever it could. The classic hydraulic tradition aimed to destroy this predatory "nature" and replace it with a docile hydraulic culture. While at the outset this project was carried out by ordinary farmers organized in mutual associations as well as by nobles and monasteries, by the late Middle Ages a group of peripatetic expert "dike masters" had come into being. At the close of the eighteenth century, care for the core hydraulic infrastructure passed to the central government with the founding of the Rijkswaterstaat, a national public works agency modeled on the French Corps des Ponts et Chaussees. During the nineteenth century, this agency became increasingly academized and professionalized (Disco 1990; Lintsen 1980) as graduates of the Civil Engineering Department at the Delft Engineering School succeeded in establishing a monopoly on engineering posts in the organization. In the course of the twentieth century, this professional monopoly was extended to the entire domain of hydraulic engineering and water management in the Netherlands, that is, to the provincial and even the local levels.

With the environmentalist wave of the early 1970s came the realization that nature was intrinsically valuable and that "civilization" had been incurring heavy ecological debts. In most national contexts, ecological damage could be seen as the unreflexive by-product of economic and political activities (which has allowed for facile scapegoating and politicization). In regard to their waterworks, however, the Dutch had to face up to the fact that ecological damage was a precondition of survival and prosperity. This created strong pressures to develop technologies that were responsive both to the old criteria of safety and prosperity and to the new criterion of ecological conservation.

The difficulty was translating this relatively clear if paradoxical political aim into actual technological practice. Given the strong and well-embedded civil engineering regime at the core of water management practices, it was clear that any decisive change would have to involve the incorporation of biological and particularly ecological expertise (and hence of ecologists) into hydraulic engineering design. This would be a question not only of new types of insights but also of new positions and organizations. A new regime in water management would require a dramatic turnaround in attitudes, personnel, knowledge, and institutions. Ancient cultural reflexes toward water as treacherous nature would have to be reexamined; new ideas and methods would have to be developed and implemented. This would by no means be a question only of rational planning but of conflicts and controversies, not only in the realm of public politics but in the realm of professional politics as well.

In this article, I argue three points about this ecological turnaround and its relationship to professional realigments. These points may be generalizable to other "regime shifts" involving ecologically reflexive design and sustainability. 
To be successful, ecological politics must at some point engage with the balance of forces in the "system of professions." Previously excluded professions with ecological missions must feel empowered to put forth new claims about legitimate intellectual authority and be enabled to share power with vested professions in their traditional bailiwicks. In short, to be effective, ecopolitics must also become professional politics.

Although professions are compelled to maintain constant vigilance over their boundaries with other professions, all too emphatic forms of struggle and controversy tend to disempower rather than empower them. This is because professional hegemony depends on rules and consensus rather than on the articulation and adjudication of claims about what constitutes appropriate expertise. Therefore, professions engaged in boundary disputes have an interest not only in winning such disputes but also in ending or at least hiding them.

Hence, professional politics tend to be furtive at best and to move as rapidly as possible from overt conflict to the reinstitutionalization of professionally sanctioned rules, generally in the context of expert bureaucracies. Hence, what begins as the opening up of the professional system in response to new political alliances and opportunities, a situation in which new kinds of knowledge can become germane, ends by becoming routine as a new professional regime, which may include new perspectives and new rules, but that at the end of the day is no less closed, authoritarian, and antidemocratic than its predecessor. These are clearly features that Maarten Hajer (1995) also ascribed to "ecomodernism."

\section{The Ecological Movement and the Oosterschelde Crisis}

In many countries, the environmentalist movement of the early 1970s targeted large infrastructural projects as potential ecological disasters. Although the attack was usually launched by adversarial environmentalist groups (Albert de la Bruheze 1992), it did not take long for political parties in democratic political establishments to appreciate the electoral potential of environmentalism. Concern for the environment began to make inroads into the electoral platforms of major political parties, and by the mid-1970s, environmentalist legislation was endemic.

In the Netherlands, this process was facilitated by the election of a coalition of Christian Democrats and Socialists led by the Socialist J. M. den Uyl in 1973. Dominated by left-wing reformers touting the slogan "imagination in power," the government explicitly coupled its fate to the new environmentalist wave. This had immediate consequences for two major infrastructural 


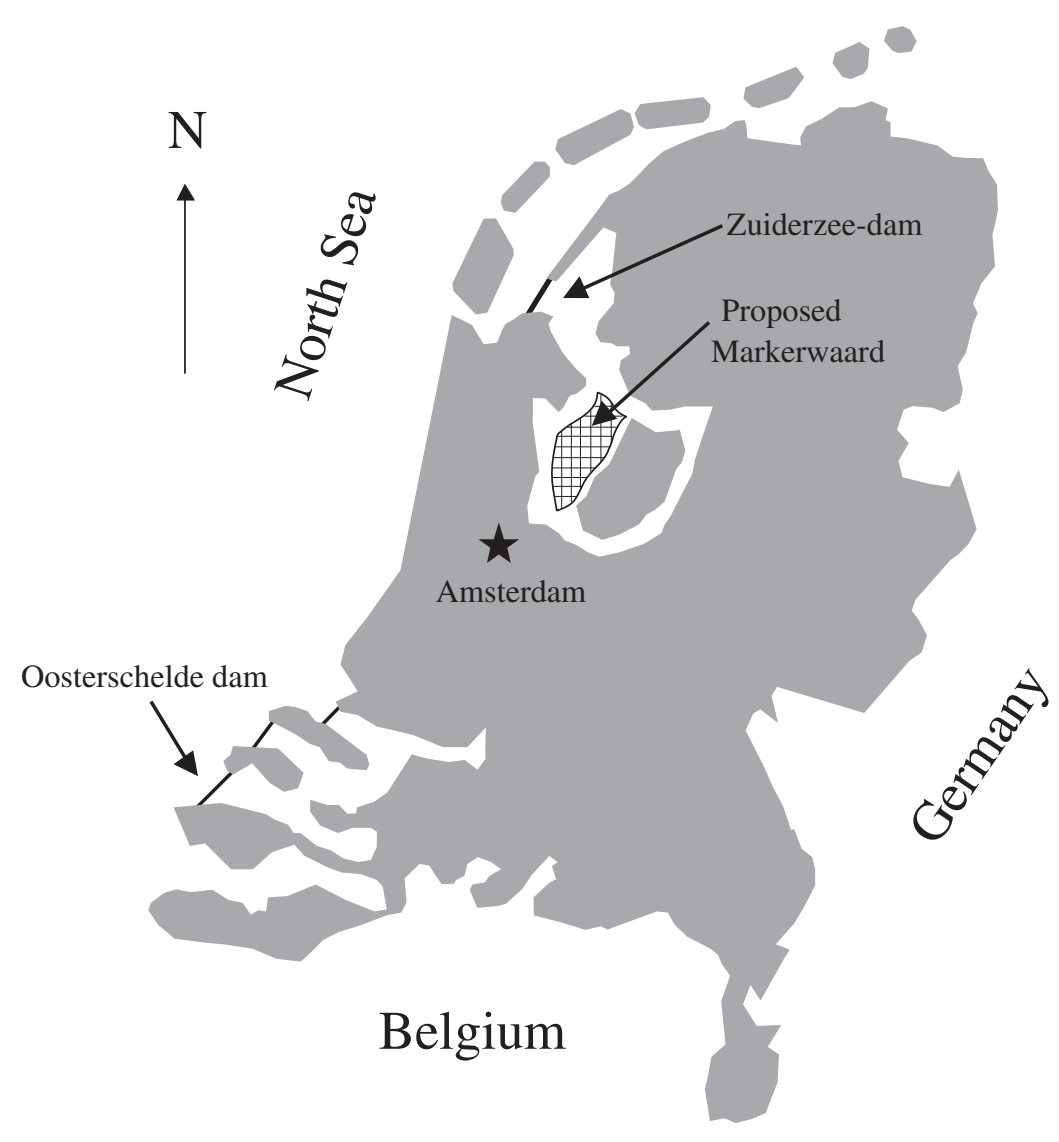

Figure 1. The Netherlands showing the closure dams in the Zuiderzee and the Southwest Delta.

projects in the domain of water management. The first was the reclamation of the Markerwaard, the final polder ${ }^{1}$ of the Zuiderzee works; the second was the proposed fixed dam in the mouth of the Oosterschelde. (see Figure 1). Praised until then as major triumphs of civil engineering, these projects rapidly became defined as environmental catastrophes.

The most dramatic and consequential episode was the struggle around the Oosterschelde, a deep and elongated maritime intrusion that had formerly been a mouth of the Scheldt River. The proposed dam would have severed the bay from the North Sea, eliminating tides and rapidly converting the unique saltwater biotope into a run-of-the-mill freshwater lake. The dam would also 
have eliminated a thriving shellfish industry. The government could not countenance this double loss and cast about for an alternative. In the event, an innovative design for a semipermeable dam saved the day. Under normal conditions, such a dam would let enough water through to preserve an ecologically and commercially viable tidal range. During so-called storm surges (unusually high water levels associated with heavy storms at sea), the dam could be closed, thus protecting the regions bordering the bay from abnormally high tides. A similar though far smaller barrier had been in service since 1958 in the river Hollandse Ijssel and had proved effective.

The ingenious compromise "spared both the cabbage and the goat," as the Dutch saying goes, and was widely touted as a political and technological triumph. Indeed, creative politics and innovative civil engineering were such visible elements of the success that later accounts seriously underplayed the significant ecological challenges involved (Bosch and van der Ham 1998; Bijker 1992, 1995; van de Poel 1998; Westerheijden 1988).

\section{The Oosterschelde Crisis Recounted}

Accounts of the Oosterschelde crisis tend to frame it as a unique political and technological episode rather than a turning point in the practice of Dutch hydraulic engineering itself. D. F. Westerheijden's (1988) exacting and exhaustive account set the tone. Westerheijden showed the entanglements between political maneuvering and technological expertise. He also occasionally provided glimpses of the roles of biologists and ecologists in the process. Nonetheless, Westerheijden focused on the politically inspired design process of the storm surge barrier itself rather than on its meaning for a new ecologized coastal engineering paradigm. The same goes for Wiebe Bijker's (1995) account, although he was obviously frying a number of methodological fish as well, not merely providing a historical or political analysis. Bijker used the Oosterschelde as a case to illustrate points about technology dynamics, such as the notion of the "seamless web." My aim is not to describe the Oosterschelde crisis as a "technological drama" (Pfaffenberger 1992), as Westerheijden did, or a methodological case in point, as Bijker did, but to historicize the crisis to show how this singular drama was the starting point for the ecological transformation of Dutch coastal engineering and water management in general.

In doing so, I use insights developed by Ibo van de Poel (1998) in his account of the Oosterschelde crisis. Van de Poel's account interprets the Oosterschelde episode not only as the crisis of a traditional "regime" of water management but also as the seedbed of a new one. It is a cusp between two socalled technological regimes in estuary closure: the old regime based on the 
absolute primacy of safety from flooding and a new regime in which compromises are sought between the demands of nature and those of "culture" (Disco and van der Meulen 1998; Disco, Rip, and van der Meulen 1992; van de Poel and Disco 1996). In van de Poel's view, the controversy issues proximately in a radically new dam design but mediately in a broad ecological learning and institutionalization process that ultimately emerges as a new basic regime called "integral water management." The added value of van de Poel's analysis is that it zooms in on the role of biologists and ecologists in the crisis. The crisis can now also be seen as a process of collective learning about how to make the discipline of ecology relevant for hydraulic engineering in general (i.e., as a technology and a politics).

Shifts in public technologies are associated not only with new political insights or constraints but also with struggles among different kinds of knowledge and knowledge bearers. What knowledge is relevant in the new situation, and who is entitled to be an authority? This calls for a perspective on professions and professional rivalry. Here, it is useful to recall Andrew Abbott's (1988) notion of "jurisdictional vacancy." Abbott's idea was that professions form an articulated "system" of expertise that more or less exhaustively tessellates the various domains of societal practice. However, given that both practices and professions evolve, new potential jurisdictions can emerge. Professions may even actively redefine practices to call the jurisdictional claims of competitors into question. Abbott called such intentional or unintentional gaps in the professional system jurisdictional vacancies, whose (re)allocations among competing professions are among the stakes in the interprofessional game.

This professional system perspective is useful for interpreting competition among professions in the Oosterschelde crisis, particularly the conflicts between biologists and ecologists on one hand and civil engineers on the other. However, to appreciate how the professional struggle was articulated with the more obvious political-technological drama, this must be augmented with something like Westerheijden's (1988) play-by-play account of the Oosterschelde as a policy crisis. The main link was formed by the Rijkswaterstaat, responsible for, among other things, designing and managing the core infrastructure of the water management system. This included the Delta Works and the closure of the Oosterschelde. The academically trained civil engineers who monopolized Rijkswaterstaat positions were quite competent in the design of hydraulic and transport infrastructure but had no training at all in the biological and ecological implications of their practice. Inasmuch as a technological solution to the Oosterschelde crisis demanded far-reaching ecological competence, the Rijkswaterstaat, particularly its Delta Department, suddenly found itself redefined as an organization 
of dilettantes rather than experts. For a brief time, this opened a very large window of opportunity for "reformist" biologists and ecologists capable of molding ecological visions to the practical demands of coastal engineering. In short, because of the political breakdown of its existing professional regime, the Rijkswaterstaat became the locus of a jurisdictional vacancy in the system of professions and of a struggle to define and occupy that vacancy.

The story of the Oosterschelde thus unfolds on one hand as a political drama directed by the government and parliament (the political bosses of the Rijkswaterstaat) and on the other hand as a struggle among various types of experts within and without the Rijkswaterstaat about technological principles and relevant types of expertise. The struggle among the experts is a struggle in the institutional rearguard. This struggle is encapsulated within the manifest political drama, but as Abbott's (1988) argument implies, it retains a logic and autonomy of its own.

The analyses by Westerheijden (1988), Bijker (1992, 1995), and Bosch and van der Ham (1998) show how the traditional safety-oriented regime in coastal engineering began to lose ground in the face of new politicized conceptions of nature and environment in the early 1970s. The growing number of fights around infrastructural projects eventually eroded the Rijkswaterstaat's political credibility. The den Uyl government found it increasingly impolitic to underwrite the Rijkswaterstaat's traditional safetyoriented regime. To save face and preserve its autonomy, the Rijkswaterstaat was now forced to come up with solutions that were both safe and ecologically acceptable, and if possible, also technologically challenging. This was the only way to restore its working relationship with the government.

The accounts just mentioned are all competent analyses of the muchpraised "win-win solution" that ultimately took shape as the Oosterschelde storm surge barrier. But the approach taken by van de Poel (1988) and Abbott (1988) takes us further. This approach invites us to look at the Oosterschelde crisis not only as a struggle among political and organizational actors but as the liberation of water management from the shackles of old structures of expertise, a cognitively ambiguous situation in which new types of experts were able to gain credence. The crisis around the Oosterschelde now appears as the cradle of ecological water management and as a first test of its political and technological robustness.

In what follows, I analyze the struggle around the Oosterschelde closure as a policy crisis that created jurisdictional vacancies and consequently opportunities for previously marginalized biologists and ecologists. A new technological regime emerged from this crisis, a regime based on the parsing of water management between the previously hegemonic civil engineers and the new breed of systems ecologists within the Rijkswaterstaat. I show 
something of how this finally crystallized into the new and highly professionalized regime of integral water management as codified in a series of government reports and in the introduction of new policy instruments, particularly the General Method for Ecological Description (AMOEBE) graphs.

\section{The Ecological Turn in Dutch Water Management}

From its beginnings, Dutch coastal engineering was based on establishing and maintaining an unbreachable line of defense against the sea. Along large sections of the central North Sea coast, a balance of natural forces had produced a barrier in the form of broad beaches and kilometers-wide chains of sand dunes. Here, it was only necessary to build groins to protect the beaches and to plant helm grass to protect the dunes. Elsewhere, notably in the southwestern delta region, around the shores of the Zuiderzee, and along the northern shores of Friesland and Groningen, artificial sea dikes were necessary. In the course of centuries, hundreds of kilometers of such sea dikes were built by local water boards (waterschappen). The construction of the dikes, to say nothing of their inspection and maintenance, proved an onerous burden on the water boards' constituencies. Moreover, local knowledge, financing, and organization produced uneven results at best, bringing with them the ever present threat (and in fact numerous instances) of calamitous flooding.

As early as the middle of the nineteenth century, plans had been forged to minimize the total length of these vulnerable dikes by damming off bays and estuaries from the sea. But it took until 1916, after major flooding in the province of North Holland, before political action was taken. In that year, a law was enacted mandating the damming of the Zuiderzee, the largest of the maritime intrusions into the country. This required building a dam thirty-two kilometers in length through open sea. The dam would have to cross a number of current-scoured tidal channels. Its construction would be a formidable challenge, but the gains would be great. The dam would replace the 250 kilometers of locally maintained dikes along the convoluted shores of the inland sea. Moreover, the dam would create a large freshwater lake, considerable portions of which could be relatively easily drained and used as farmland, no mean consideration in the midst of World War I. An important side benefit, at least from the perspective of the Rijkswaterstaat, was the centralization and professionalization of the northern coastal defenses (Bijker 1995).

With the closure of the Zuiderzee in 1932, the situation in the North appeared to be under control. Nonetheless, the hereditary enemy still had 
enough other weak spots from which to choose. In February 1953, during spring tide, a ferocious northwesterly storm lashed heavy seas over the dikes in the southwestern delta region. The dikes were breached in more than a hundred places. In the course of one night, 1,800 human lives were lost, and countless cattle drowned. Damage to property was extensive. Thousands of hectares of fertile farmland were inundated by salt water. The day after, still in the throes of rescue operations, the Rijkswaterstaat, together with the affected provinces and water boards and a number of large contractors, started repairing the damage. Within the month, the Rijkswaterstaat was advancing a long-cherished plan to close off the dangerous estuaries (with the exception of the seaward approaches to the harbors of Antwerp and Rotterdam). It was obvious from the start that the traditional technologies used in building the Zuiderzee dam would be no match for the strong currents and deep tidal channels of the delta. Entirely new closure technologies would have to be developed, for example, the use of "permeable," reinforced concrete caissons for final closure operations and the dumping of huge concrete blocks from overhead cable cars and even helicopters to build dams in open seas. No price seemed too high to ensure the statistical level of safety of one flood per 4,000 years. ${ }^{3}$

This mammoth project, which in the end took more than thirty years to complete, was without question the apotheosis of the old safety-based regime in coastal engineering. In this political and technological context, other values, particularly the preservation of nature and the environment, were simply brushed aside. The Rijkswaterstaat, at least at the outset of the Delta Works, was opportunistically blind to the suppression of concerns other than safety. In the earlier Zuiderzee closure, the same resolve had carried the day in spite of sustained and desperate protests by the Zuiderzee's saltwater fishermen, who stood to lose their livelihood. Their plaint fell on deaf ears. They were few, and the safety of many was at issue. Moreover, there were prospects of much new land and an enormous freshwater reservoir; the general opinion was that the plight of the fishermen did not justify foregoing these benefits. The fishermen, moreover, could be (and in fact were) compensated for their losses, at least in a material sense.

It was no secret that damming off the Zeeland estuaries would destroy unique and irreplaceable estuarine environments, not to mention a highly profitable shellfish and fishing industry. But this was a price that the Rijkswaterstaat engineers and the nation had already paid in the case of the Zuiderzee, and it was a price that many seemed willing to pay again. That too had been the consequence of a suspect but nonetheless popular policy. As early as 1955 , the proceedings of a conference on the Delta Works noted, 
Safety compels the closure of the estuaries. This implies a certain loss of natural values which must be accepted. What will be lost, however, is no small thing. The dynamic character of the Delta region will be lost-probably not entirely but surely for the most part. Tidal effects and saline gradients will be eliminated at most places. In any case, the three most important regions, the Oosterschelde, the Haringvliet and the Biesbosch, together with their surroundings, will be utterly transformed.

The consequence is that in biological terms the major portion of the Delta region is facing strong impoverishment. Numerous plant and animal species and an even greater number of highly specific combinations will be lost forever. The effects will most likely extend much further than we can now oversee. It is not impossible that we will be facing unexpected problems years from now. (Rijkswaterstaat 1998, 7)

Gone, but not forgotten. Similar concerns about threatened and ruined ecotopes resurfaced with the environmental movement of the early 1970s. Infrastructural projects that until then had been showcases of modernist aspirations and technique now became sites for fierce dissent. Major highway projects were challenged, and in the domain of water management, reclamation projects and dams were especially targeted. In the case of the last of the Zuiderzeepolders (the Markerwaard), the issue was still relatively simple: was new land a more valuable asset than existing fresh water? In the case of the Oosterschelde, the question was much more radical and complex: was timely protection against flooding more important than the preservation of a saltwater ecosystem and associated fisheries? A question such as this would have seemed absurd not only in centuries past but even as recently as 1965 .

\section{The Oosterschelde: Finale and Turning Point}

The Delta Works were officially launched in late 1953, and throughout the 1960s, they were widely celebrated as an expression of Dutch national vitality and Dutch civil engineering prowess in particular. The closing of each successive estuary was marked by festivities attended by royalty and other notables. While engineers and politicians congratulated one another, tugboats carefully maneuvered the massive final caisson into position. The following day, banner headlines proclaimed the new triumph over the forces of nature. By 1972, work had begun on the final and most difficult closure, that of the Oosterschelde. At the proposed closure point, the Oosterschelde was no less than eight kilometers wide. The dam would have to cross currentscoured channels of up to forty meters in depth. During construction, the dam had to resist both fierce tidal currents and the fury of the North Sea's storms and waves. It was clear to everyone that this was going to demand world-class 
hydraulic engineering, indeed, the most impressive feat of coastal engineering ever undertaken in the Netherlands.

Building on the experience gained in previous closures, the Delta Works Department of the Rijkswaterstaat faced the Oosterschelde challenge with confidence. However, in contrast to the previous projects, the closure of the Oosterschelde had been controversial from the very beginning. In the early 1960s, Parliament had debated the economic drawbacks of closing off the estuary. From the first, there had been a viable alternative to closure that would have spared the mussels, the oysters, and the unique ecology: namely, reinforcing and heightening the existing dikes around the estuary. But the modernistic Rijkswaterstaat preferred starting with a clean slate: rather than mucking with ancient and unreliable dikes, it opted for heroic and innovative hydraulic projects. The "father of the Delta Works," civil engineer Dr. Johan van Veen (1962), made the point succinctly:

There were two quite different possibilities. First, heightening hundreds of miles of ancient and unreliable dikes, which in the course of several centuries have been broken at thousands of different places and always repaired in a hurry. Secondly to make the short, strong line of defence wholly reliable and of modern construction. (p. 182)

But in the political climate of the early 1970s, the closed dam option became a target of massive and persistent popular opposition. The protest was articulated by a pragmatic coalition called Oosterschelde Open. The coalition united a number of ad hoc local interest groups (mostly shellfish entrepreneurs and yacht owners) with "universalistic," nationally organized environmentalist groups. Such a coalition was a formidable political adversary for two reasons. First, it involved such a diversity of actors and interests, from the sacred to the profane, that it was difficult to discredit the movement as either a self-interested not-in-my-backyard movement or the work of idealistic ecopuritans. Second, by bringing the economic storyline to the forefront in some contexts and the environmentalist storyline in others, the coalition was able to recruit very diverse allies. Advocates of special economic and regional interests (such as the Ministry of Economic Affairs and the Provincial Estates of Zeeland) now found themselves espousing the same cause as the environmental movement.

In spite of this strong and growing opposition, however, neither the government nor Parliament was at first inclined to delay the Oosterschelde closure. The 1973 elections changed that from one day to the next. Den Uyl's new center-left coalition saw the environment as a core issue. In fact, one of 
the planks in the platform that got the left-wing parties elected was a promise to reevaluate the Oosterschelde closure. They wasted little time in appointing the Oosterschelde Committee. At the time, a preliminary design for a semipermeable storm surge barrier (proposed by a number of civil engineering students at the Delft Engineering School) was attracting public attention. The Oosterschelde Committee was charged with investigating the feasibility and costs of such a solution.

The disciplinary composition of the Oosterschelde Committee broke with reigning conventions. Until then, government committees in the domain of water management had been composed exclusively of civil engineering graduates of the Delft Institute of Technology, excepting the occasional lawyer. Now, however, disciplinary heterogeneity carried the day. Only two of the seven members were civil engineers (only one of whom was a hydraulic engineer). The chairman was a lawyer and former governor of the province of South Holland. The remaining six members included a civil engineer (specializing in coastal engineering), an economist, a biologist, a fisheries expert, an environmental expert, and a regional planner (the second civil engineer).

The committee reported to the government on 1 March 1974, just six months later. It rejected the fixed dam option as environmentally and economically undesirable and recommended several possible variations on the theme of a storm surge barrier. A central question, aside from the actual design of the barrier, was how to construct it without having to reduce the tidal aperture for so long and to such an extent as to cause irreversible damage to the ecosystem whose survival was at stake in the first place. Without an environmentally conservative solution for the actual construction process, no final design could be considered feasible. Westerheijden's (1988) account makes it clear that the committee's solution to this intricate problem was taken seriously in hydraulic engineering circles, despite its hybrid composition. One of the reasons was that the committee's plan was in fact developed in close consultation with hydraulic engineers, including members of the Delta Department of the Rijkswaterstaat. This was because the Delta Department possessed crucial data about the Oosterschelde.

The Delta Department itself nonetheless stuck to its original closure plans. It took a very critical public stance toward the Oosterschelde Committee and touted a fixed dam as the only sensible option. According to the Delta Department, the new plans were either too expensive, would require the ecologically unacceptable closure of the estuary during construction, or would take so long to build that the risk of an intervening catastrophic flood would be unacceptably high (Westerheijden 1988, 163). Ultimately, however, it proved impossible for the Delta Department to maintain this increasingly eccentric stance. As a gesture of political loyalty, it requested the contractors' 
consortium for the Delta Works to do a feasibility study for one of the committee's options. This gesture was sufficiently reassuring for Parliament to decree in November 1974 that the Oosterschelde should be closed off from the sea by means of a permeable storm surge barrier. The decision was conditional on the technical feasibility of the plans and on cost and time constraints.

What had happened? Riding a wave of popular disenchantment with environmentally destructive megaprojects, the new left-wing government had been able to distance itself from the existing plans for the Oosterschelde. This was a slap in the face for the Rijkswaterstaat, which still hewed to the traditional coastal engineering regime based on commitments to land reclamation and safety from flooding (van de Poel and Disco 1996). The government did not deny the importance of safety but now wished to weigh the environmental costs of a fixed dam against the safety, feasibility, and environmental compatibility of alternative closure options. This could hardly have been expected of the Rijkswaterstaat itself, which was technically and organizationally committed to the fixed dam. But to convince Parliament and the public that other options were possible, the government clearly had to muster its own technological expertise, first to discredit the Rijkswaterstaat's approach on economic and environmental grounds and second to come up with an alternative that was persuasive enough to reengage the Rijkswaterstaat in the process of designing alternatives.

That, of course, had been the task of the Oosterschelde Committee. Its well-argued hybrid solution was a challenge the Rijkswaterstaat could not refuse, for two reasons. First, it challenged the Rijkswaterstaat's cherished hydraulic engineering expertise: could an innovative storm surge barrier be built, and if so, how? Second, it challenged the Rijkswaterstaat's loyalty to an ecologically militant government: could such a barrier be built in an ecologically acceptable manner, and if so, what were the appropriate ecological criteria? The Oosterschelde Committee had come up with a preliminary plan, and now, the ball was clearly in the Delta Department's court. The point of departure was utterly clear: no solution would now be accepted that did not respect the ecological integrity of the Oosterschelde. So, the Delta Department found itself in the dilemma of either abandoning a barrier altogether and opting for simply raising the dikes or thinking out a practicable and ecologically viable design for a storm surge barrier. While the first option would have kept faith with its long tradition of antiecological engineering solutions, it would also have been a total retreat from the letter and the spirit of the Delta plan. The second option would salvage the leitmotif of closure but at the cost of admitting biologists and ecologists as equal partners in design. Parliament had in any case left little latitude for soul searching on this point because it had already, albeit provisionally, mandated a storm surge barrier. The Delta 
Department's immediate and pressing task was simply to assess whether the provisions could be met. It soon became apparent that its ecological expertise was completely inadequate to the task.

The investigation proceeded along two main fronts. First, a study was conducted of alternative designs for storm surge barriers with different maximum apertures. The results were presented to parliament in the form of the so-called Blue Report in May 1976. This study did not draw heavily on detailed ecological expertise but simply accepted a certain minimum tidal range as the basic ecological constraint and avoided alternatives calling for full closure for extended periods during construction. Second, a background analysis was conducted to provide a fallback "policy cushion" in the event that the proposed storm surge barrier proved too expensive for Parliament (Westerheijden 1988, 223). This investigation was summarized in the socalled White Report, submitted conjointly with the Blue Report. This second report was drawn up at the behest of the new chief of the Delta Department. The idea was to provide enough new data and arguments so that possible new deliberations on the Oosterschelde could proceed intelligently without a time-consuming new crisis. Speed was important to the Rijkswaterstaat in view of the still deplorable state of the dikes around the Oosterschelde and the ever present possibility of a repetition of the 1953 storm.

The White Report was based on a study called Protecting an Estuary from Floods-Policy Analysis of the Oosterschelde (POLANO) (Goeller, Abrahamse, and Bigelow 1977). The study compared three options for the Oosterschelde: open but with improved dikes, closed, and semiclosed by means of a storm surge barrier. A range of criteria was involved, but the study concentrated most heavily on costs, safety, and ecology. The Rijkswaterstaat had contracted with the prestigious RAND Corporation to carry out the study, doubtless because of its own limited expertise but certainly also because of the greater political clout of an "independent" study. RAND's model makers worked closely with members of the Delta Department's Environmental Unit to define parameters and methods, and it is clear that the study was not only innovative but also an important learning experience for the Rijkswaterstaat. RAND, which at the time knew little about ecology but a lot about systems analysis and computers, managed to establish a lower limit for the barrier aperture on the basis of a quantitative ecosystem analysis of the Oosterschelde. Below this level, there would be "detrimental" effects on the existing ecosystem. This provided the first firm ecological parameters for the design of the storm surge barrier. On the basis of its ecosystem model, RAND could categorically advise against a closed Oosterschelde. On the other hand, RAND predicted, that ecologically speaking, a completely open Ooster- 
schelde would be difficult to distinguish from one with a storm surge barrier having an aperture in excess of 6,500 square meters.

The ecological section of the POLANO study (Goeller, Abrahamse, and Bigelow 1977) was based on an innovative "energetic" systems ecology model, that is, an approach that conceptualized the ecosystem not as a community of discrete biological species but more abstractly as a system of energy inputs, throughflows, and outputs based on nutrient cycles and a "food web" among a very limited number of biological groups (Pastoors 1992). By thus simplifying the ecosystem and redefining it as a system of abstract quantities, RAND succeeded in operationalizing ecology as a design parameter in a civil engineering context. Thanks to the drastic reduction in the number of variables achieved by grouping species and thanks to the use of digital computers, it was now possible to model different ecological states and outcomes on the basis of different civil engineering options for the Oosterschelde. RAND had given Dutch ecologists and civil engineers the first clues on how to fill in the gaping jurisdictional vacancy on the ecological aspects of coastal engineering projects.

The two reports convinced the government to advocate the storm surge barrier. In June 1976, Parliament followed suit. The Rijkswaterstaat was once again at bat. It now had a clear mandate to develop a detailed design for a storm surge barrier as defined by the Oosterschelde Committee and the two Rijkswaterstaat reports. Designing this barrier was, as noted, an innovative civil engineering challenge of the first order. The impressive technical achievement has been recounted often. Here, I want to emphasize that to create the design, ecological experts (professional biologists and ecologists) were necessary partners at every step of the way. Van de Poel (1998) argued that their involvement was crucial in at least four key decisions on the Oosterschelde storm surge barrier:

1. The decision about the magnitude of the aperture in the storm surge barrier

2. The decision about the closing strategies of the barrier in relation to the design of the barrier

3. The role of ecological concerns during the final construction works, and

4. Ecological monitoring for the later management of the area

In spite of dramatic cost overruns, the barrier became the figurehead of a new approach in Dutch water management, a hybrid construction simultaneously serving the interests of safety, economy, and ecology. It demonstrated that these interests were not essentially opposed but could be technologically aligned. In particular, the permeable Oosterschelde barrier demonstrated that ecologically informed design did not necessarily preclude old-fashioned 
hydraulic engineering glamour. It was an invitation to civil engineers to embrace ecologically informed design. More projects such as the Oosterschelde barrier now became a hydraulic engineering consummation devoutly to be wished for, even if ecologists and their concerns now also had to share in the pie.

\section{The Ecological Reconstruction of the Delta Department}

The physical barrier itself was only a material symbol of the new approach. RAND's hard-headed ecosystem study was at least as influential as the barrier itself inasmuch as it provided an acceptable framework for the new hybridized practice of integrating ecological criteria into coastal engineering projects. The reliance on ecosystem theory, computer-based mathematical modeling, and field measurements for the critical parameters of the model in fact fit the Rijkswaterstaat's already highly quantified civil engineering culture like a glove. As far as the Rijkswaterstaat's biologists and ecologists were concerned, adopting RAND's style gave them a forceful language vis-à-vis the hegemonic civil engineers. This created the trust that enabled them to become participants in subsequent coastal engineering projects and to achieve policy-making power within the Rijkswaterstaat. Ultimately, it enabled them to become an important force in all domains of Dutch water management.

In fact, the ecological turnaround on the Oosterschelde Dam had paved the way for the entry of biologists, chemists, and ecologists into the Rijkswaterstaat in the first place. ${ }^{4}$ The Oosterschelde crisis was, to use a phrase coined by Prime Minister den Uyl, the point of departure for the ecologists' "long march through the institutions." Biologists and ecologists made their debut in a special unit of the Delta Department set up to manage the effects and integration of the closure projects, for example, managing the new freshwater systems, alleviating negative side effects of the new dams, and designing and implementing peripheral infrastructure such as roads and recreational facilities. As Table 1 shows, in 1970, the unit was called the Department of Water Management, Ancillary Works, and Facilities Delta Lakes. In that year, at least on the basis of formal training, no one in the department was professionally qualified to carry out an "environmental" task. It was staffed entirely by civil engineers and subsidiary technicians. In 1971, the Rijkswaterstaat hired its first university-educated biologist, H.L.F. Saeijs. His arrival marked the founding of a unit devoted explicitly to environmental research. By 1975, when RAND's POLANO study (Goeller, Abrahamse, and Bigelow 1977) was underway, the unit had been renamed 


\section{Table 1. Delta Department Environmental Research, 1970 to 1985}

\begin{tabular}{|c|c|c|c|c|}
\hline Year & Organizational Unit & $\begin{array}{l}\text { Environmental } \\
\text { Personnel }\end{array}$ & $\begin{array}{l}\text { Disciplinary } \\
\text { Representation }\end{array}$ & $\begin{array}{l}\text { Diffusion of Environmental } \\
\text { Research in Rijkswaterstaat }\end{array}$ \\
\hline 1970 & $\begin{array}{l}\text { Department for Water Management, } \\
\text { Ancillary Works and Facilities Delta Lakes }\end{array}$ & 0 of 15 & $\begin{array}{l}6 \text { CE, } 0 \text { univ., } 3 \text { HTS, } \\
10 \text { tech. }\end{array}$ & RIZA ${ }^{a}$, Delta Department \\
\hline 1972 & $\begin{array}{l}\text { Department for Water Management, Ancillary } \\
\text { Works and Facilities Delta Lakes; Sub-Unit for } \\
\text { Environmental Research and Prognosis (1971) }\end{array}$ & 12 of $29^{b}$ & $\begin{array}{l}2 \text { CE, } 1 \text { biologist (H.L.F. Saeijs), } \\
1 \text { HTS, } 8 \text { tech. }\end{array}$ & RIZA, Delta Department \\
\hline 1975 & $\begin{array}{l}\text { Department of Environmental Research } \\
\text { and Facilities }\end{array}$ & 21 of $33^{b}$ & $\begin{array}{l}\text { Department head is CE; } \\
\text { Sub-Unit for Environmental } \\
\text { Research: } 5 \text { univ. (top } 5 \text { posi- } \\
\text { tions), } 0 \text { CE, } 8 \text { HTS, } 8 \text { tech. }\end{array}$ & RIZA, Delta Department \\
\hline 1980 & Division of Environment and Facilities & 14 of $21^{b}$ & $\begin{array}{l}\text { Division head is CE; Department } \\
\text { of Environmental Research: } \\
\text { Saeijs head; top } 6 \text { positions: } \\
5 \text { univ. + } 1 \text { CE, } 9 \text { total univ., } \\
4 \text { total CE, } 1 \text { tech. }\end{array}$ & RIZA, Delta Department \\
\hline 1985 & Division of Environment and Facilities & 15 of $21^{b}$ & $\begin{array}{l}\text { Division head is CE, Land and } \\
\text { Water Departments head CE, } \\
\text { Land Department } 4 \text { univ + } \\
2 \text { CE,Water Department } \\
4 \text { univ. + } 4 \text { CE + } 2 \text { HTS }\end{array}$ & $\begin{array}{l}\text { Early } 1982, \text { Saeijs to Central Staff } \\
\text { Division as policy maker. } 1990 \\
\text { to } 1999, \text { Saeijs chief engineer } \\
\text { director in Zeeland (regular line } \\
\text { function). }\end{array}$ \\
\hline
\end{tabular}

SOURCE: Staatsalmanak voor het Koninkrijk der Nederlanden (s'Gravenhage, Staatsdrukkerij- en Uitgeverijbedrijf), 1970, 1972, 1975, 1980, 1985.

NOTE: $C E$ = a civil engineer who graduated from Delft Institute of Technology; univ. = a regular university graduate, likely a biologist or ecologist, possibly a chemist; $\mathrm{HTS}=$ a graduate of a higher technical school, discipline unknown; tech. = a nondegree technician; RIZA = National Institute for the Purification of Waste-Water.

a. See text, note 4.

N b. The first figure denotes the number in the environmental unit. The second is the total for the department or division as a whole. (Both figures are irrespective of training or discipline.) 
Department of Environmental Research and Facilities. The subunit devoted to environmental research employed twenty-one of the thirty-three members of the department. None of the twenty-one were civil engineers. University academics, almost certainly biologists and ecologists, occupied the top five positions in the unit. Sixteen higher technical school engineers and technicians provided support. These data suggest that under pressure of the Oosterschelde crisis, the Delft-trained civil engineers were having to surrender some of their authority to biological and ecological experts. This was of course only a marginal shift in the context of overwhelming civil-engineering dominance in the rest of the Delta Department, not to mention the Rijkswaterstaat as a whole.

However, Table 1 also suggests that after 1975, the influx of biologists and ecologists began to stagnate in favor of the renewed presence of civil engineers. This may be because new cohorts of civil engineers, educated in the wake of the Report of the Club of Rome (Meadows and Franken 1972), had begun to develop ecological interests and competencies of their own. This is not all that surprising, given the formal affinity of the systems approach in ecology with standard hydraulic modeling and simulation practices. Also, of course, civil engineers continued to occupy most of the bureaucratic line positions in the Delta Department and tended to be the hierarchical chiefs of the biologists and ecologists, who were usually younger. In any case, by 1980, the environmental unit was headed by the veteran biologist Saeijs, and four university biologists or ecologists and one civil engineer shared the top five positions. The full complement of fourteen was made good by an additional four university graduates (presumably biologists or ecologists), three civil engineers, and a technician. By 1985, the environmental unit as such had been split into units for "land" ecology and "water" ecology. Both units were headed by civil engineers (as was the department as a whole), and one might conclude that the old civil engineering culture was reasserting itself. This, however, could well be an artifact of the data (i.e., academic titles). The hypothesis is that additional more complex data would reveal the spread of ecological consciousness and expertise to younger cohorts of civil engineers and would hence betray a new cultural mode of integration of ecological criteria into civil engineering design practices. The "ecosystems approach" in water management would be more a matter of rules and routines than of people and disciplines. Additional research would be necessary to decide this point. 


\section{Integral Water Management in the Making}

\section{A Sea of Reports}

In the meantime, the ecological perspective was consolidating beachheads elsewhere in the Rijkswaterstaat. In 1983, the agency's veteran biologist, H.L.F. Saeijs, was named head of the Department of Waterhousehold of the Division of Water Barriers, Reclamation and Waterhousehold of the Central Directorate of the Rijkswaterstaat in the Hague. His task there was to develop policy proposals for what was called the national "waterhousehold." In 1942, the director-general of the Rijkswaterstaat, L. R. Wentholt, gave the classical definition of this concept:

The management of the levels of water and the safeguarding of its quality, seen from a national perspective.... [This] should take place in a unified way, based on mutual trust and cooperation between those national and provincial institutions that are active in this area. (Saeijs 1995, 7)

This mutual trust and cooperation seemed all the more essential given Wentholt's perception of the political tensions among stakeholders: "The different interests, such as those of shippers, industry, agriculture, public water supply, public health, fisheries, and sewerage will sometimes be diametrically opposed" (Saeijs 1995, 8).

In the event, Wentholt's visionary program was only partially realized. The major accomplishment was a national system for the redistribution of Rhine water, completed in 1970 with the commissioning of the large Rhine sluices at the seaward end of the Haringvliet estuary, also an integral part of the Delta Works. A thoroughgoing implementation of Wentholt's idea suffered from his removal from office by the occupying German authorities in 1943, his subsequent ironic postwar incarceration on charges of cooperation with the enemy, the economic priorities of the postwar reconstruction period, and finally the tragic flood of 1953 . The latter, as we have seen, stimulated a new era of massive hydraulic infrastructure construction embodied in the Delta Plan, in which safety was the prime consideration to the exclusion of all else.

Saeijs's new task as head of the department originally created by Wentholt was to revitalize the notion of the waterhousehold. But given who he was, such revitalization would inevitably redefine water quality in terms of its ecological rather than merely chemical properties and potentials. Saeijs, in short, was now in a position to develop a hegemonic concept of the waterhousehold 
in which ecological quality replaced the much more limited criterion of chemical quality. This of course also implied a new definition of the classical management of water quantity.

The diffusion of the hard-won ecological wisdom of the Delta Department into the Rijkswaterstaat organization and from there to other locations in the world of Dutch water management was not only a matter of bureaucratic naming, learning, and the circulation of experts (e.g., Saeijs) but equally of the creation and circulation of texts. The most conspicuous of these were the series of occasional reports on the national waterhousehold that appeared roughly every ten years starting in 1968 . The reports were prepared by the Rijkswaterstaat at the behest of Parliament and in effect specified the ruling government's medium-term policy objectives in the domain of water management.

As a complement to the safety priorities embodied in the Delta Works, the first of these reports (1968) emphasized the quantity of available freshwater as the key water management problem. Freshwater is essential for agriculture, the public water supply, and the desalinization of newly reclaimed polders. This regime of "freshwater supply" (waterhousehold in a classical but limited sense) intersected with the safety regime, inasmuch as the Delta Works also provided for the construction of several very large freshwater storage basins (e.g., the former Haringvliet estuary). The report did of course mention water quality, but only in the limited sense of levels of inorganic pollution, particularly of salt levels. In this sense, the first waterhousehold report was actually a throwback to debates that had taken place in the 1930s in connection with the closure of the Zuiderzee and fears that it might prove impossible to keep the salinity of the resulting lake low enough for agricultural and water supply purposes.

In contrast to its chary treatment in the first waterhousehold report, water quality was the core concern of the Law on Surface Water Pollution of 1970. The law covered organic as well as inorganic pollutants and required that all wastewater be treated, either at the source or in large regional treatment facilities. However, this law did not provide for a centrally coordinated system of water quality management but instead enjoined the provinces to see to it that water purification systems were set up at local levels. The actual implementation of the new law (including the construction and operation of the sewage treatment plants) subsequently devolved on existing local water boards or in some cases on new "purification boards."

The Second Report on the Waterhousehold appeared in 1984. It was a radical departure from the first report and was an important step toward the articulation of what would soon become known as integral water management. The second report can be read as a response to the environmental crisis of the 
1970s and as a summary of earlier internal reports and studies related to the closing of the Oosterschelde as well as to freshwater management in general. The Second Report on the Waterhousehold attempted to defuse political tensions by incorporating some of the goals of environmentalist groups into official water management policy and, indeed, inviting their limited participation. In this sense, it was a better-late-than-never type of response to the Markerwaard and to the Oosterschelde crises.

But it was also a response to the long, hot, and unusually dry summer of 1976, during which not only the quantity but also the quality of available freshwater supplies deteriorated precipitously. The brand new national waterhousehold system came perilously close to collapsing under these extreme conditions. The government responded by commissioning the RAND Corporation and the national Hydraulic Laboratory in Delft (with the Rijkswaterstaat as sparring partner) to do a policy study of freshwater distribution. This so-called PAWN study (Policy Analysis for the Water Management of the Netherlands) took six years to complete and laid solid foundations for a new systematic and multidimensional approach to the management of the waterhousehold. The PAWN study entailed an inventory of the freshwater requirements per category of consumer. The aims of the study were to clarify the relationships among the various freshwater interests, identify potential areas of conflict, and make appropriate policy suggestions. In this sense, the report adumbrated the new politics of the coming "integral" revolution in the waterhousehold. The Second Report on the Waterhousehold of 1984 drew heavily on the PAWN conclusions. As described in the Third Report on the Waterhousehold (Rijkswaterstaat 1989), the Second Report expressed "a first effort at an integral systems approach, whereby groundwater and surface water, water quantity and water quality were viewed in their mutual interrelationships" (p. 22).

Saeijs, meanwhile, was working on other pieces of the integral water management puzzle. In 1982, he defended a doctoral dissertation called Changing Estuaries: A Review and New Strategy for Management and Design in Coastal Engineering. The dissertation emerged out of Saeijs's own experience with designing and managing the ecological aspects of the Oosterschelde closure, including the RAND studies. His point of departure was that steering and monitoring ecological changes required an "integral systems approach." So, one sees a convergence of two distinct discourses: first, the academic discipline of applied ecology embodied in Saeijs's work and second, reflection on complex multistakeholder policy processes as embodied in the POLANO (Goeller, Abrahamse, and Bigelow 1977) and PAWN studies and the Second Report on the Waterhousehold. The discursive point of convergence in the combined perspective was now the integral 
systems approach. The textual site of convergence was a Rijkswaterstaat memorandum called Living with Water written by Saeijs (1985) and published just a year after the Second Report. Saeijs's memorandum took the step that was still missing in the Second Report by integrating the ecopolitical legacy of the Oosterschelde into the emergent integral water policy approach. Saeijs argued that biological aspects, particularly water-based ecosystems, should also become an integral part of the concept of "water system."

This claim was explicated in the Third Report on the Waterhousehold, published just four years later (Rijkswaterstaat 1989). Here, integral water management was presented as an ecologically sensitive, hybrid politicaltechnological approach to water management policy. The Third Report on the Waterhousehold developed a conception of the "internal functional coherence" of water systems. This refers to the integration of different material aspects of water systems simultaneously with the integration of the different managerial levels impinging on those water systems. This complex has been visualized as a "water system cube." The cube is a three-dimensional matrix with three categories for each dimension. Two of the dimensions refer to aspects of the physical water system. The first of these divides the morphology of water systems into three substructures: water, water bottoms, and shores. The second dimension expresses the three qualitative aspects of each of these morphological elements: physical, chemical, and biological. The third dimension expresses the three governmental levels impinging on water systems: the national level, the provincial level, and the local level of the water boards. A fastidious analyst could thus discriminate 27 different intersections, each consisting of one substructure, one aspect, and one governmental level. The idea of this graphic device is first to prevent any systematic lapses of attention in water management and second to encourage hydraulic planners to take as many of the relevant overlaps and interconnections into account as possible when framing new projects.

But the water system cube is only a hopeful visualization, a bookkeeping device for keeping track of elements and aspects in relation to the different levels of government. More to the point are the centrally established water quality norms, which were worked out in the Third Report on the Waterhousehold (Rijkswaterstaat 1989) and subsequent appendices. These norms were tied to a limited number of "management functions" attributable to specific water systems (e.g., water for shipping, swimming, fishing, drinking, recreation, or nature). Water quality norms were established for each of these functions across all nine combinations of elements (water, bottoms, shores) and aspects (physical, chemical, biological). These norms were then used to derive targets for each specific water system on the basis of a number of measurable parameters. 


\section{Ecology as the Measure of All Things: The AMOEBE and Integral Water Management}

Prior to the Oosterschelde controversy, the most systematically neglected elements of water systems were the shores and water bottoms, and the most systematically neglected aspect was the biological one. To develop different integral management options for these neglected elements and aspects, it was necessary to develop a quantitative and preferably also visually incisive method for evaluating aquatic biological communities. Biological quality was certainly a function of the physical and chemical quality of the water systems. This meant that a measure of biological quality would also be indicative, at least to some extent, of the other two dimensions of quality. Biology here meant ecology, and the basic measure of quality was the relative proportion of species in any given ecosystem. Other things being equal, the greater the diversity of species, the healthier an aquatic ecosystem was held to be.

But this open-ended goal could hardly serve as a practical directive for actual water management policy. What was needed was some absolute ecological calibration point that could serve as a standard against which to evaluate the present condition and with respect to which interested parties could bargain about realistic futures. Given its projected role in aligning the different levels of water management and in bargaining among different policy sectors in the political arena, the standard had to be credible and transparent, even for nonexperts.

The solution was the so-called AMOEBE, developed by one of the working groups for the Third Report on the Waterhousehold (Rijkswaterstaat 1989), the working group on Nature for the Salt Waters (van der Windt 1995b). AMOEBE is a Dutch acronym denoting General Method for Ecological Description. AMOEBEs are graphic devices capable of dramatizing the gap between the present biological condition of a given water system and its (putative) condition in a standard reference year, sufficiently long ago to qualitatively predate current levels of human pollution, yet not so far in the past that reliable biological data are lacking. For the river ecology AMOEBEs, the reference year adopted was 1900; for the maritime AMOEBEs, the year was 1930.

How does an AMOEBE work? The graph compares quantities of a set of "reference species" in the present against quantities in the standard reference year. The reference species are held to comprise a full ecological profile of the type of water system in question, including algae, plants, insects, fish, mammals, and birds. The numbers of individuals per species in the standard reference years are set out on the circumference of a circle of convenient radius. Hence, for each species, the same unit radius represents the number of 
individuals counted in the type of ecosystem in the standard reference year. Next, the number of individuals per species for the water system being described is plotted as a proportional distance along the same polar coordinate provided for that species in the reference year. If, for example, there are twice as many individuals in the present water system as there were in the reference year, the point will be plotted at a distance of $2 r$ along the species coordinate (where $r$ is the radius of the standard year reference circle). By subsequently connecting the endpoints of these radial distances, the characteristic amoeba shape appears, often deviating dramatically from the perfect circle that would denote zero environmental impact, at least relative to the reference year (see Figure 2).

AMOEBEs have now made their way into all kinds of reports and have become important policy instruments in integral water management. They are readily interpretable, they communicate a dramatic message of ecological distortion and destruction, and they explicitly couple water management to the integrity of prehuman biological systems (and no longer primarily to traditional physical or chemical systems). The AMOEBEs, moreover, are not only a diagnostic tool but also an efficient way to quantify and visualize policy goals against the background of the ever present ideal of the reference situation in which human impact on natural ecosystems is defined as minimal or at least tolerable.

Whereas the water system cube is primarily a mnemonic device to coordinate the so-called internal functional interrelationships of water management, the AMOEBEs, among other descriptive strategies, also operate to coordinate the "external functional interrelationships" (van der Windt 1995a). The latter is in fact the fundamental political and technological challenge of integral water management because it is a strategy to eliminate overt political conflict and to realize the "harmonization" of disparate interests in the policy process. Van der Windt (1995a) stressed the overt professional interests involved in designing and propagating the AMOEBE, in effect sustaining Abbott's thesis on jurisdictional vacancies:

The history of the AMOEBE can in the first instance be understood as the triumphal march of a group of scientists centering on the ecologist Ten Brink [a Rijkswaterstaat ecologist and originator of the AMOEBE] who succeeded in bringing about new (meaning) couplings and (social) bindings. Ten Brink was well aware of the field within which he had to operate, with its diverse interests and groups. The task facing Ten Brink, the Working Group on Nature (of Salt Waters) and the Department of Tidal Waters (of the Rijkswaterstaat) was to show that they could add something to the ... field of actors, such that they were able to connect up with the most important players and orientations. They had to be sufficiently different from other ecologists and defenders of nature to 


\section{Situatie 1988 (rivier-amoebe)}

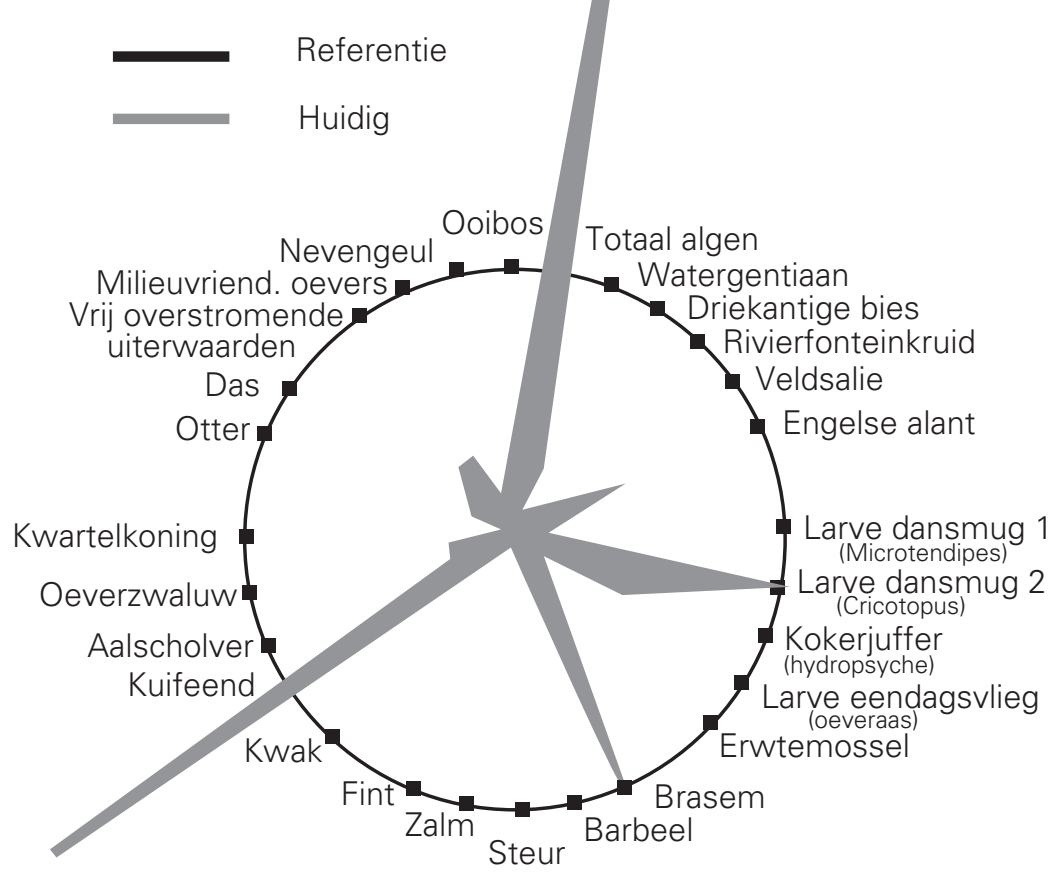

Figure 2. An AMOEBE diagram for a large Dutch river in 1988. Quantities of various species and morphological features are indicated by the grey areas relative to the reference year 1900 (points on the circle).

fit within the Rijkswaterstaat, but not so different as to endanger their links to other ecologists and to nature- and environmental protection groups. (P. 260)

Van der Windt (1995a) depicted the AMOEBE as a conceptual linking device, or "boundary object" (Star and Griesemer 1989) not only among different organizations and actors in the water management field but also among different sectors of the ecological profession and movement. The AMOEBE had to be able to link the Rijkswaterstaat ecologists both to the old civil engineering hierarchy of their own organization and to the ecological profession at large. The AMOEBE thus had to be and in fact was designed to offer clear 
and above all quantifiable guidelines for hydraulic policy while delivering unambiguous normative judgments about the (poor) state of present aquatic ecological systems. This made it a relevant feature of the emergent "ecomodernist" (Hajer 1995) paradigm of integral water management: always on the alert for win-win situations between the conflicting claims of modernizing economies and deteriorating nature.

\section{Conclusion}

An important dynamic in the emergence of integral water management is what Andrew Abbott (1988) characterized as encroachments by professional groups into "vacancies" in the division of labor of the "system of professions." In Abbott's view, professions (as "macroactors" and as collections of individual practitioners) always seek to expand their professional territories. Seeing the system of professions as a zero-sum game, Abbott argued that professions expand in the fashion of predators: domains neglected or poorly serviced become objects of contestation among vying professions and ultimately an object of conquest by one or more of them. Something like this happened within the Delta Department of the Rijkswaterstaat in the wake of the political bankruptcy of the project to close off the Oosterschelde estuary with a fixed dam. The environmental and economic opposition to the closing of the Oosterschelde declared a verdict of no-confidence in the hydraulic engineers who had been in control until then. They had no choice but to begin to share power in the Delta Department with biologists and ecologists. The latter were quick to parlay this foot in the door into a permanent structural claim on resources within the Rijkswaterstaat and ultimately within the domain of Dutch water management as a whole.

This interpretation gains credibility in view of lateral judgments from the perspective of the now institutionalizing paradigm of integral water management. Thus the biologist Saeijs, veteran of the Environmental Unit of the Delta Department, main author of the Third Report on the Waterhousehold (Rijkswaterstaat 1989), and until 1999 chief engineer and director of the Rijkswaterstaat in the province of Zeeland, took the classical hydraulic engineering paradigm to task and in the process positioned the new ecological one. In the old paradigm, argued Saeijs (1995),

excessive priority is given to the construction of more and ever larger hydraulic works. Much more emphasis should be placed on management instead of construction. I know, if you've made something beautiful you can show what you're capable of. With a storm surge barrier you can carry kings and presidents into 
transports of wonder. But for a well-functioning salt Grevelingenmeer [one of the other former Delta estuaries] so clear that you can see to depths of 8 meters in the summer, you can't even get a pat on the back from a lackey. If you perform well as manager, no matter how complicated and complex the processes underlying management-that's nothing special. That's what's expected. Nonetheless, it's an art to make adequate use of the physical, chemical, and biological processes of the ecosystem, to move it in the desired direction, making as much use as possible of its self-regulating processes which keep the ecosystem intact. (P. 30)

Reading this only a little between the lines, one senses the professional ressentiment of a biologist now come into his own but who for years had to compete with the builders of huge and spectacular civil engineering works for recognition, budgets, and authority. Saeijs's (1995) potshot reinterprets the heroic tradition of civil engineering as an infantile pursuit of power and glory, while in the wings, mature biologists patiently struggle with their delicate ecosystems. The above-mentioned "father of the Delta Works," Johan van Veen (1962), spent slack time in the final years of World War II writing an (excusably nationalistic) history of Dutch water. Van Veen saw a noble Dutch tradition of reclamation and hydraulic defense carried on from generation to generation by an elite he called the "masters of the floods," a tradition clearly culminating in his own person and in the Delta Works. Saeijs claimed that these past masters have been seriously overrated and that the time was ripe for the "masters of the ecosystems" (p. 234).

But power corrupts, even ecological power. Saeijs (1995) had no interest in understanding that the new regime, however much it emphasizes criteria such as "sustainability," is trapped in the ironies of ecomodernism. In spite of its revolutionary goals, it is incapable of escaping the old structures of technocratic power. In fact, it is precisely because it does not eschew authoritarian expertise as a means (i.e., precisely because it is organized around a new professional practice rather than around a new politics) that it can be so successful. Just like the erstwhile masters of the floods, the new masters of ecology are encapsulating processes of consensual decision making within a system of technocratic rules, images and models. Plus ça change, plus ça reste le même.

\section{Notes}

1. A polder is reclaimed land lying below the level of mean high tide. It is surrounded by protective dikes and drained by pumping out excess water.

2. Abbott's (1988) idea was directly inspired by seminal Chicago School work on intra- and interprofessional conflicts, particularly that of Rue Bucher (1962) and Anselm Strauss (Bucher and Strauss 1961). 
3. This chance of flooding was based on statistical expectations of very high water levels caused by conjunctions of spring tides and storms. The norm for the sparsely populated and agricultural Zeeland part of the delta was one flood every 4,000 years. For the densely populated central part of the country, it was set at one flood every 10,000 years.

4. Biologists were already active at other sites within the Ministry of Traffic and Waterworks in policy-making positions. Since 1920, a special agency called the National Institute for the Purification of Waste-Water (RIZA) had existed, which in the nature of things had employed a number of chemists and biologists. However, at the time of the events described in this article, RIZA was not part of the Rijkswaterstaat organization, which set up an institutional barrier to the diffusion of biological issues within the Rijkswaterstaat. Moreover, the RIZA had a specific bailiwick (propagating wastewater treatment) that touched the concerns of the Rijkswaterstaat only tangentially. RIZA's chemists and biologists toiled in a different vineyard, which at that time was not connected to the management of water quantity (van Luin and Hulshof 1995).

\section{References}

Abbott, A. 1988. The system of professions: An essay on the division of expert labor. Chicago: University of Chicago Press.

Albert de la Bruheze, A. A. 1992. Political construction of technology: Nuclear waste disposal in the United States. Twente, the Netherlands: University of Twente Press.

Beck, U. 1992. Risk society: Toward a new modernity. Newbury Park, CA: Sage.

Bijker, W. 1993. Dutch, dikes and democracy: An argument against democratic, flexible, good and bad technologies. Technology Assessment Texts 11. Lyngby, DK: Unit of Technology Assessment, The Technical University of Denmark.

- 1995. Sociohistorical technology studies. In Handbook of science and technology studies, edited by S. Jasanoff, G. E. Markle, J. C. Peterson, and T. Pinch, 229-56. Thousand Oaks, CA: Sage.

Bosch, T., and W. van der Ham. 1998. Twee Eeuwen Rijkswaterstaat: 1798-1998. Zaltbommel, the Netherlands: Europese Bibliotheek.

Bucher, R. 1962. Pathology: A study of social movements within a profession. Social Problems 10:40-51.

Bucher, R., and A. Strauss. 1961. Professions in process. American Journal of Sociology 66:32534.

Carson, R. 1964. Silent spring. New York: Fawcett Crest.

Disco, C. 1990. Made in Delft: Professional engineering in the Netherlands 1880-1940. Unpublished diss., University of Amsterdam.

Disco, C., and B. van der Meulen, eds. 1998. Getting new technologies together: Studies in making sociotechnical order. Berlin, Germany: Walter de Gruyter.

Disco, C., A. Rip, and B. van der Meulen. 1992. Technical innovation and the universities: Divisions of labor in cosmopolitan technical regimes. Social Science Information 31 (3): 465507.

Goeller, B. F., A. F. Abrahamse, and J. H. Bigelow. 1977. Protecting an estuary from floods: Policy analysis of the Oosterschelde. Vol. 1, Summary report. Santa Monica, CA: RAND.

Hajer, M. A. 1995. The politics of environmental discourse: Ecological modernization and the policy process. Oxford, UK: Clarendon.

Lash, S., B. Szerszinski, and B. Wynne, eds. 1996. Risk, environment and modernity: Towards a new ecology. Thousand Oaks, CA: Sage. 
Lintsen, H. 1980. Nederlandse Ingenieurs in de Negentiende Eeuw: Een Streven naar Erkenning en Macht. The Hague, the Netherlands: Martinus Nijhoff.

Meadows, D. L., and F. Franken. 1972. Rapport van de Club van Rome. Utrecht, the Netherlands: Uitgeverij Het Spectrum.

Pastoors, M. 1992. The Oosterschelde revisited: Evaluation of ecological modelling in the POLANO-project (policy analysis of the Oosterschelde) 1974-1977. Amsterdam, the Netherlands: University of Amsterdam, Department of Science Dynamics.

Pfaffenberger, B. 1992. Technological dramas. Science, Technology, \& Human Values 17:282312.

Rijkswaterstaat. 1989. Derde Nota Waterhuishouding.. The Hague, the Netherlands: Tweede Kamer Staten Generaal.

-1998. MER beheer Haringvlietsluizen: Over de grens van zout en zoet. The Hague, the Netherlands: Rijkswaterstaat, Directie Zuid Holland.

Saeijs, H.L.F. 1985. Omgaan met Water. The Hague, the Netherlands: Rijkswaterstaat.

1995. Levend Water en een Wereldstad: Ecologie als Economische Factor in het Waterbeheer. Rotterdam, the Netherlands: Erasmus University.

Star, L. S., and J. R. Griesemer. 1989. Institutional ecology, translations and boundary objects: Amateurs and professionals in Berkeley's Museum of Vertebrate Zoology, 1907-1939. Social Studies of Science 19:387-420.

van de Poel, I. 1998. Changing technologies. Twente, the Netherlands: University of Twente Press.

van de Poel, I., and C. Disco. 1996. Influencing technology: Design worlds and their legitimacy. In The role of design in the shaping of technology, edited by J. Perrin and D. Vinck, 93-129. Brussels, Belgium: European Commission.

van der Ven, G., ed. 1993. Leefbaar Laagland: Geschiedenis van de waterbeheersing en landaanwinning in Nederland. Utrecht, NL: Matrijs Publishers.

van der Windt, H. J. 1995a. De amoebe als verbeelding der natuur. Kennis en Methode 3:251-76. 1995b. En dan: Wat is Natuur nog in dit Land? Amsterdam, the Netherlands: Boom.

van Luin, A. B., and J. E. Hulshof. 1995. RIZA: 75 jaar deskundig in water. Lelystad, the Netherlands: Stichting IVIO.

van Veen, J. 1962. Dredge, drain, reclaim: The art of a nation. The Hague, the Netherlands: Martinus Nijhoff.

Westerheijden, D. F. 1988. Schuiven in de Oosterschelde: Besluitvorming rond de Oosterschelde 1973-1976. Twente, the Netherlands: Universiteit Twente, Faculteit Bestuurskunde.

Cornelis Disco teaches at the Center for Studies of Science, Technology and Society at the University of Twente. He has published on technology dynamics and the recent history of technology, focusing on the history of Dutch water management. He is presently editing a book section on Dutch cities and urban technologies in the twentieth century in the context of a national project in the history of Dutch technology in the twentieth century. He is also participating in a similar urban technology project at the European level. 